\title{
ИСТОРИЯ ЯЗЫКА
}

УДК: 81'255.4:82.03:811.111:821.161.1-1

DOI: 10.22363/2313-2299-2018-9-4-795-811

\section{«РУССКИЕ ПЕСНИ» АНТОНА ДЕЛЬВИГА: ПРОБЛЕМА СОХРАНЕНИЯ НАЦИОНАЛЬНОГО КОЛОРИТА В АНГЛИЙСКИХ ПЕРЕВОДАХ}

\author{
М.Н. Ненарокова \\ Институт мировой литературы им. М. Горького РАН \\ ул. Поварская 25а, г. Москва, Россия, 121069
}

\begin{abstract}
Статья посвящена проблеме передачи национальной специфики текста в переводе. Объектом изучения стали «русские песни» Антона Дельвига, стилизации под народные песни, созданные с использованием поэтических средств русского фольклора. Предметом изучения стали особенности передачи признаков национального колорита, отличающих стихотворения Дельвига, в английских переводах. Исследование выполнено на материале следующих текстов: семь переводов стихотворения «Соловей», два перевода стихотворения «Пела, пела пташечка...», один перевод стихотворения «Ах, ты, ночь...», один перевод стихотворения «Не осенний частый дождичек...», выполненных как русскоязычными, так и англоязычными переводчиками. Автор поставил себе цель определить, какими художественными средствами можно передать национальные особенности стилизации под русскую народную песню. В задачи исследователя входило: проанализировать и описать особенности передачи метрики стихотворений Дельвига; определить круг их ключевых лексем; выявить и описать расхождения в их переводах, объяснить, почему вариант, выбранный тем или иным переводчиком, возможен или невозможен в переводе текста Дельвига; указать, какими способами переводчики воспроизводят на английском языке художественные средства русской народной песни; определить, как назначение текста связано с ожидаемым результатом работы переводчика. Были использованы методы сплошной выборки, лингвистического наблюдения и описания, компонентного анализа, концептуального анализа, контекстуального анализа, анализа сочетаемости слов. Исследование показало, что переводчики, сохраняющие национальную специфику оригинала, создают перевод-стилизацию. Они повторяют средствами своего языка художественные средства оригинала. Арсенал художественных средств, позволяющий передать национальную специфику в случае «русских песен» Дельвига, складывался в течение полутора столетий. Он включает в себя использование архаизмов, передачу повторов и параллелизмов, воссоздание формул или создание аналогов в рамках своей культуры. Важным средством передачи национальной специфики текста является его ритм. Точное воспроизведение ритмического рисунка помогает читателю получить то же впечатление от перевода, что и от оригинала, и даже может замаскировать ошибки в передаче содержания.
\end{abstract}

Ключевые слова: перевод, национальная специфика, русская литература, фольклор, русская песня, Антон Дельвиг, стилизация, поэтические средства, «Соловей»

\section{ВВЕДЕНИЕ}

Одной из труднейших проблем, с которыми сталкивается в своей работе переводчик, является передача национальной специфики текста. Национальная специфика может проявляться в тексте заметно, в виде разнообразных реалий, не суще- 
ствующих в принимающем языке, как языковых, так и культурных и исторических. Часто сложность возникает не только и не столько в том, чтобы в переводе были сохранены и правильно переданы имена, названия предметов домашнего обихода, одежды, национальных блюд, праздников, упоминания об исторических событиях, - мимо таких элементов текста переводчику трудно пройти, они представляют собой заметные препятствия, без преодоления каждого из которых невозможно продолжать работу и в конце концов достигнуть результата. Как кажется, гораздо более трудно передать стиль произведения, особенно если произведение написано с использованием лексики, отклоняющейся от литературных норм, например, диалектной, относится к устному народному творчеству или является стилизацией, воспроизводящей основные черты того или иного фольклорного жанра.

Говоря о стилях жанров устного народного творчества, например, о стиле народной песни, исследователи выделяют, с одной стороны, «языковую основу песни - диалект (разговорную речь)» [1. С. 8], с другой, «совокупность поэтических приемов» [1. С. 8], воспользовавшись которыми можно создать авторское литературное произведение. Выраженность национального колорита в нем зависит от умения автора грамотно использовать художественные средства народной поэзии.

Интересным примером подобных литературных произведений можно назвать «русские песни» Антона Дельвига (1798-1831). Антон Антонович Дельвиг, вошедший в историю русской литературы как лицейский друг Пушкина, «представитель „пушкинской плеяды“» [2. С. 5], «был одной из самых примечательных фигур в русской литературе пушкинской эпохи» [3. С. 3].

\section{ДЕЛЬВИГ И ЕГО «РУССКИЕ ПЕСНИ»}

Дельвиг начал писать в то время, когда в русском обществе были особенно сильны патриотические настроения, вызванные событиями 1812 г. Недаром первым его известным стихотворением является «патриотическая стилизация народной песни по случаю занятия Москвы Наполеоном» [3. С. 4-5].

Интерес к русскому фольклору сохранился у Дельвига на всю жизнь, поэтому значительную и, возможно, наиболее известную часть его наследия составляют так называемые «русские песни и романсы». Свое общее название эти стихотворения Дельвига получили недаром: многие современники в своих воспоминаниях отмечали, что на их тексты очень быстро стали писать музыку, иногда сразу по прочтении. Так, рассказывая в своих мемуарах о салоне Софьи Дмитриевны Пономаревой, частым посетителем которого был и Дельвиг, Д.Н. Свербеев отмечал: «Дельвиг приносил свои песни, которые тут же распевала хозяйка» [4. С. 30].

Как писал исследователь литературы пушкинского времени Б.В. Томашевский, «песни Дельвига, конечно, не реставрация крестьянской обрядовой или бытовой лирики. ... Они писаны в „народном стиле“, так, как он понимался в те годы и на потребу тогдашнего времени» [2. С. 50]. По наблюдениям Л. Плоткина, «в песнях Дельвига совершенно отсутствуют архаические слова и обороты, ... он смело вводит в свои стихи разговорные интонации, средства фольклорной поэ- 
тики» [5. С. 41-42]. То же подтверждает и Л. Колер, американская исследовательница творчества Дельвига: «Он [Дельвиг - М.Н.] не использует каких-либо грубых, „вульгарных“ выражений и таким образом вполне соответствует классицистическим представлениям о подражаниях народной песне, предназначенных в первую очередь для литературного салона. <...> Язык в общем и целом проще, более разговорный [чем в „классических“ стихотворениях [6. Р. 177], М.Н.], но все еще в границах нейтрального стиля» [6. С. 176-177]. Она перечисляет поэтические средства, почерпнутые Дельвигом из народных песен: «широкое использование слов с уменьшительно-ласкательными суффиксами» [6. Р. 177], «особые „жалобные“ выражения: кручинушка, сиротинушка...» [6. Р. 177], «формульные эпитеты из народной поэзии» [6. Р. 177], «использование деепричастий на -учи, -ючи, характерное для народной песни» [6. Р. 177], «слова с ударением, как в народных песнях» [6. Р. 177], «параллелизм, повтор, сравнения, символические образы» [6. Р. 178]

Тот факт, что дельвиговы «русские песни» «изначально имели установку на вокальное исполнение» [7. С. 22], определил их дальнейшую судьбу и в России, и за рубежом. Большинство песен и романсов на стихи Дельвига до сих пор входят в певческий репертуар, в том числе и «Пела, пела пташечка...» на музыку А.А. Алябьева, и «Не осенний мелкий дождичек...» на музыку М. Глинки, исполнявшийся еще Федором Шаляпиным, и «Ах, ты, ночь...» также на музыку М. Глинки, и, конечно, знаменитый «Соловей», наиболее известную музыку к которому написал А.А. Алябьев. Все четыре названные «русские песни» были переведены на английский язык.

\section{АНАЛИЗ ПЕРЕВОДОВ СТИХОТВОРЕНИЯ «РУССКАЯ ПЕСНЯ» («СОЛОВЕЙ МОЙ, СОЛОВЕЙ...») (1826)}

Настоящее заглавие стихотворения, которое весь мир знает на разных языках как «Соловей», было «Русская песня» [8. С. 31]. Имя автора самого раннего перевода, включенного в рецензию на сборники «славянской» поэзии, одним из которых была книга Songs of the Polish and Russian People of Galicia, collected by Wenceslaus Olesky. Lemberg. 1833 («Песни польского и русского народа Галиции, собранные Венцеславом Олеским») [9. Р. 85], установить не удалось (возможно, это сам автор статьи). Дельвиг выводится в этой рецензии как фольклорист, «записавший песню из уст крестьянской девушки» [9. Р. 106]. Название стихотворения впервые изменено: The Faithless Lover [10. Р. 107; 6. Р. 177], «Неверный возлюбленный».

На сегодняшний день обнаружено еще шесть переводов этого стихотворения: авторами переводов являются Александр Шарковский (2011 г.) [11], Людмила Пургина $^{1}$ (2012 г.) [12], Алекс Дэвис (2014 г.) [13], Эдуард Лейтман (2014 г.) [14], английский литературовед и переводчик Питер Франс (2015 г.) [15] и Александр Ласкавцев (2016 г.) [16].

${ }^{1}$ В Интернете фамилия переводчицы приводится только по-английски - Purgina, отсюда наша транслитерация. 
Необходимо отметить, что только половина авторов перевела текст Дельвига полностью или с небольшими купюрами (переводы Анонима, Шарковского, Пургиной, Франса).

Две первые строки стихотворения Дельвига «Соловей мой, соловей, / Голосистый соловей!» [8. С. 31] переданы по-английски почти одинаково всеми переводчиками. Главным камнем преткновения для переводчиков стал эпитет соловья — «голосистый». Русское прилагательное «голосистый» значит «обладающий богатым, сильным, звучным голосом». Стоит также уточнить, что понимается под богатством и звучностью голоса. Богатый голос отличается не только красивым тембром, но и наличием дополнительных звуков, обертонов. Чем больше обертонов, тем богаче голос. Звучность голоса предполагает «громкость, звонкость, чистое звучание». Соответственно, чистота голоса соотносится с отсутствием фальшивых нот, сипения, хрипоты. Такой голос приятен слушателям. Можно сказать, что у прилагательного «голосистый» есть признаки «громкость», «богатство», «чистота» и связанная с ними «красота/приятность». Это прилагательное разделило переводчиков на две группы.

Англоязычные переводчики передали один или несколько признаков голоса соловья, например, Дэвис подчеркнул громкость пения (Loud-voiced nightingale [13. Р. 87] — «громкоголосый соловей»), а Франс — и громкость, и приятность (Sweet-voiced, loud-voiced nightingale [15] - «Сладкоголосый, громкоголосый соловей»). По этому же пути пошел и один из русскоязычных переводчиков, Лейтман: Sweetly singing Nightingale [14] — «сладко поющий соловей». Аноним прибегнул к описательному переводу: Nightingale so full of song [10. Р. 107] «соловей, столь полный песней».

Большинство русскоязычных переводчиков выбрало слово vociferous $[11 ; 12$; 16], и, как кажется, выбор этот малоудачен. Это прилагательное для английского читателя связано не с пением, а с защитой и пропагандой своих убеждений: «выражающий свое мнение или чувства громко и уверенно»; «выражающий чувства или мнения очень громко и убедительно»; «если вы описываете кого-то как vociferous, вы даете понять, что эти люди говорят очень энергично и решительно, так как они хотят, чтобы их мнение было услышано». Как кажется, более правы переводчики, передававшие признаки слова «голосистый». Они гораздо меньше погрешили против смысла слова.

Строки 3 и 4 в оригинале представляют собой одно вопросительное предложение. Фольклорный характер предложению придает повтор вопросительного слова «куда»: «Ты куда, куда летишь...» [8. С. 31]. Переводчик 19 в. постарался воссоздать повтор, но иными средствами. Он расширил текст перевода посредством добавления, но при этом нельзя сказать, что перевод неудачен: Tell me, tell me, where thou fliest [10. Р. 107] — «Скажи мне, скажи мне, куда ты летишь...». В тексте появляется разговорная интонация, не противоречащая характеру народной песни. С другой стороны, аноним 19 в. употребляет архаичные формы thou - «ты» и fliest — «летишь», поскольку в переводах с русского языка, сделанных в 19 в., архаичные формы использовались для передачи народной, крестьянской речи. 
Большинство переводчиков постаралось сохранить повтор, причем они делали это разными способами: Where, where are you flying to — «Куда, куда ты [сейчас] летишь...» [16]; Where do you fly? Where to do you fly? — «Куда ты летишь? Куда ты летишь?» [12]; Where are you flying to, oh where? — «Куда ты [сейчас] летишь, о, куда?» [15].

Как говорилось выше, строка 4 является второй частью сложносочиненного бессоюзного предложения, но некоторые переводчики изменяют его структуру, создавая два независимых вопросительных предложения, как, например, делает это Лейтман: Where are you flying by alone? / Where you'll be singing all night long? [14] — «Куда ты пролетаешь мимо в одиночестве? Где ты будешь петь ночь напролет?» Людмила Пургина делит дельвиговское предложение на три части: Where do you fly? Where to do you fly? / Where do you sing your trills all over the night? [12] — «Куда ты летишь? Куда ты летишь? Где ты поешь свои трели в течение всей ночи?» В других переводах первоначальная структура предложения сохраняется, например у Ласкавцева: Where, where are you flying to, / Where will you be singing all night long? [16] — «Куда, куда ты [сейчас] летишь, / Где ты будешь петь ночь напролёт?»

Если повтор «куда, куда» переводчикам воспроизвести удалось, то уменьшительное «ночка» можно отнести к неизбежным потерям. В английском языке уменьшительных суффиксов немного, и по объему значения они далеко не всегда совпадают с русскими суффиксами. Дельвиговское «ночка» во всех переводах теряет свой народный, фольклорный характер и передается нейтральным night.

Строки 5-8 стихотворения представляют собой вопросительное предложение, осложненное двумя деепричастными оборотами, причем параллелизм этих оборотов поддерживается еще и рифмой («смыкаючи» - «утопаючи»), в то время как в стихотворении рифма на концах строк отсутствует. Особенностью этих деепричастий является окончание «-ючи», придающее, как и параллелизм, фольклорный характер тексту Дельвига. В этих четырех строках переводчикам пришлось решать несколько проблем, и первой из них была передача пола лирической героини. Как писал в статье «Славянская народная поэзия» аноним, в качестве героинь русских народных песен выступают «крестьянские девушки» [9. Р. 106], «де́вицы», поэтому в переводе, включенный в статью, аноним использует архаизм, вошедший в язык английской поэзии, maiden - «лит. дева, девушка или незамужняя молодая женщина»: Will another maiden hear thee / Like to me... [10. P. 107] «Будет ли другая дева слушать тебя, / как я...». Это же существительное использует и Питер Франс в своем переводе: Will some poor maiden just like me / Hear уои...[15] — «Будет ли какая-нибудь бедная дева так же, как и я, / Слушать тебя...». Поскольку использование архаизмов характерно для перевода русских фольклорных текстов, можно сказать, что здесь переводчикам удалось передать русский народный колорит.

Лирическая героиня говорит и о себе, и о возможной товарке по несчастью: «бедная». В русском языке «бедный» как характеристика душевного состояния может означать «несчастный, возбуждающий жалость, сострадание, несчастный, жалкий». Прилагательное «несчастный» можно объяснить как «испытывающий 
или испытавший несчастье; выражающий горестное, скорбное состояние», но так же и как «жалкий», то есть «жалкий, ничтожный», если словом «несчастный» выражается неодобрительное, пренебрежительное отношение к человеку или предмету. Поскольку все эти слова используются в словарных дефинициях прилагательного «бедный», то, как кажется, его значение могут отличать такие компоненты, как «горе, страдание», «сострадание, сочувствие», «ощущение жалости к себе или другому», причем эта жалость имеет легкий негативный оттенок.

Только в одном случае, в тексте Людмилы Пургиной [12], эпитет опущен. Остальные переводчики передали его при помощи английских прилагательных. Англоязычные переводчики [10. Р. 107; 13. Р. 88-89; 15] были единодушны в выборе poor в значении «заслуживающий жалости и симпатии». Таким образом, значения слов poor и «бедный» почти совпадают, если не учитывать тонкую разницу между положительным роог и слегка презрительным «бедный». Что касается русскоязычных переводчиков, то выбор их был различен: как и его англоязычные коллеги, Лейтман использовал poor [14], в то время как Ласкавцев остановил свой выбор на wretched [16], а Шарковский отдал предпочтение sorrowful [11]. Английское прилагательное wretched может значить «крайне дурной или неприятный», а также «вызывающий симпатию и жалость». Wretched могло бы совпадать по значению с русским прилагательным «бедный», если бы не оттенок сильного раздражения: последнее, разговорное, значение слова wretched - «вызывающий очень сильное раздражение».

Прилагательное sorrowful - «очень печальный», выбранное Шарковским, отражает один из компонентов, входящих в значение прилагательного «бедный», а именно: «выражающий горестное, скорбное состояние». Как кажется, более нейтральное poor гораздо лучше соответствует замыслу Дельвига, создававшего «,русские песни“, сближавшиеся с народными песнями... особенностями художественного языка» [7. Р. 5].

Текст Дэвиса показывает, как опасен буквальный перевод. В то время как остальные переводчики передавали глагол «прослушать» («Кто-то бедная, как я, / Ночь прослушает тебя...» [8. С. 31]) английскими глаголами hear [10. Р. 107; 12; 15] и listen $[11 ; 14 ; 16]$, Дэвис прибегнул к поморфемному переводу, создав сложное слово failed-to-hear [13. Р. 89] — букв. «не удалось услышать». Очевидно, в погоне за точностью возникла путаница между двумя омонимами: один из глаголов-омонимов «прослушать» означает «слушать в течение какого-то времени», другой «отвлекшись, не услышать».

Как уже было сказано выше, строки 5-8 отличает использование параллелизма, характерное для русской народной поэзии, в частности для песен. Передача русских грамматических форм и рифмы на английском языке невозможна, но один из переводчиков постарался передать сам принцип параллелизма: Will another maiden hear thee / Like to me, poor me, all night / Sleepless, restless, comfortless, / Ever full of tears her eyes? - «Будет ли другая дева внимать тебе, / Как я, бедная я, всю ночь / Без сна, без отдыха, без покоя, / С глазами, полными слез?» [10. Р. 107]. Здесь переводчик сохранил сам прием, используя прилагательные, построенные по одной словообразовательной модели с одним и тем же суффиксом -less: 
Sleepless, restless, comfortless. Во всех остальных переводах отсутствие параллелизма можно отнести к переводческим потерям.

В строках 9-12 «Ты лети, мой соловей, / Хоть за тридевять земель, / Хоть за синие моря, / На чужие берега» [8. Р. 31] находим детали, типичные для устного народного творчества: «тридевять земель» и «синие моря».

Выражение «тридевять земель», по сути своей сказочная формула, не нашло себе равноценного аналога в переводах. У переводчиков было два пути - либо перевести формулу дословно и, таким образом, сохранить фольклорный колорит, либо искать какие-то словосочетания-заместители. Только англоязычные переводчики попытались сохранить сказочную формулу. Аноним создал аналог, также содержащий числительное - «сто». В английском фольклоре не приписывается особого значения числу «сто», хотя, конечно, есть значимые для фольклорной традиции числа больше ста [17. Р. 237], так что «сто морей» может быть вписано в собственную фольклорную традицию.

Питер Франс пошел по другому пути. У него дельвиговское «за тридевять земель» получило аналог beyond the gates of earth [15] — «за врата земли». Как кажется, это отсылка к германской мифологии, согласно которой Срединный Мир, земля людей, огорожен стеной, в которой были сделаны ворота. Здесь происходит замена русской сказочной формулы новосозданной формулой, источником которой является германская фольклорная традиция.

Другое выражение Дельвига — «синие моря» - соотносится с фольклорным «сине море», сохраняя народную окраску и в то же время принадлежа литературному языку. Известно, что в английском языке прилагательное blue может означать и «синий», и «голубой». Анониму the blue sea [10. Р. 107] - «синее море» показалось, видимо, достаточным, а те современные переводчики, которые сосредоточились на передаче фольклорного характера этой детали, старались подчеркнуть темный цвет морской воды: the dark blue of the seas [13. Р. 89] — «темная синь морей», beyond the dark blue sea [15] — «за темно-синее море». Двое других переводчиков, как кажется, решили передать именно цвет моря, не придавая значения фольклорной формульности. У Шарковского читаем: over distant stormy seas [11] - «за далекие бурные моря», а вода во время шторма в море темнеет, так что морская синева в его переводе все же не утеряна. Пургина использовала другое прилагательное, azure [12], - «ярко-голубой цвет, похожий на цвет неба», при помощи которого можно описать море, но этот эпитет относится скорее к области художественной, авторской литературы, а не фольклора.

Самым ярким словом строк 13-16 оказывается сравнительная степень прилагательного «горемышнее» [8. С. 31] (так написал сам Дельвиг). Прилагательное «горемычный» означает: «Постоянно преследуемый несчастьями, бедами; несчастный (о человеке); преисполненный горя; тяжелый, безрадостный; выражающий горе, печаль». Прилагательное «горемычный» дало в переводе шесть вариантов. Двое переводчиков использовали нейтральное poor [12] - «вызывающий жалость и симпатию» и sorrowful [11] - «очень печальный, выражающий горестное, скорбное состояние», причем в переводе Шарковского это прилагательное повторяется дважды. 
Аноним понимает «горемычный» как sad: Whether thou find'st any one, / Who so sad is, as I am! [10. Р. 107] — «Обретешь ли ты кого-нибудь, / Кто был бы столь несчастен, сколь я!».

В этом переводе акцент делается на ощущении несчастья, переживании горя, причиной которых было какое-то событие. У Дэвиса находим unlucky: you will not find anywhere else one as / unlucky as me [13. Р. 90] — «ты нигде не найдешь никого, столь же невезучего, сколь я», поскольку unlucky указывает на несчастье, причиной которого являются не отсутствие способностей или трудолюбия, а случайность, невезение. Прилагательное miserable было выбрано двумя переводчиками - Ласкавцевым и Франсом: You wouldn't have found anywhere / The more miserable one, than I am [16] — «Ты бы не нашел никого нигде / более знающегося с горем, чем я»; you'll never find in any land, / in any village, any town, / a maiden as miserable as mе [15] — «ть никогда не найдешь в какой-либо стране / в какой-либо деревне, в каком-либо городе / деву, столь же знающуюся с горем, сколь я», при этом miserable означает «глубоко несчастный и при этом испытывающий чувство тревоги, страха, смущения», «вызывающий жалость тем, что находится в состоянии душевного страдания или несчастья, например, от нужды или стыда»; «глубоко несчастный». Как видим, прилагательное выражает довольно сложное чувство.

Наконец, последним вариантом перевода «горемычный» является прилагательное hapless, использованное Лейтманом: Nowhere you will see / Girls that hapless more than me [14] — «Нигде ты не увидишь / девушек, что неудачливы более меня» (пропущен глагол-связка). В значение прилагательного hapless входят такие компоненты, как «невезение», «неудачливость», «неуспешность» как причины «несчастья». Как кажется, вариант miserable подходит для перевода «горемычный» лучше всего.

В строках 17-20: «У меня ли у младой / Дорог жемчуг на груди, / У меня ли у младой / Жар-колечко на руке» [8. С. 31] аноним, и Шарковский правильно поняли «дорог жемчуг» как «дорогое жемчужное ожерелье» В таком значении слово «жемчуг» в русском языке употребляется. В переводах находим не только упоминание «ожерелья», но и попытку передать смысл краткой формы прилагательного «дорогой» - «дорог». Оба переводчика употребляют слово necklace [10. Р. 107; 11]. Если Шарковский употребляет прилагательное precious - «редкий, ценный, стоящий много денег», что по силе значения несколько превосходит русское прилагательное «дорогой», то аноним передает ценность «дорогого жемчуга» описательно: O, I bore a necklace once, / All of pearls like morning dew [10. Р. 107] — «О, некогда я носила ожерелье, / Все из жемчужин, похожих на утреннюю росу».

«Жар-колечко» является неологизмом, созданным Дельвигом. Первая часть сложного слова «жар-» восходит к выражению «гореть как жар», то есть «сиять, сверкать, блистать, искриться, переливаться». Таким образом, «жар-кольцо» может и блестеть само по себе, если в нем нет камня, но может и иметь вставку. Аноним понял «жар-колечко» именно как «кольцо с камнем-вставкой»: ... I bore a fingerring, / With a precious stone thereon [10. Р. 107] — «И я носила кольцо на пальце / С драгоценным камнем в нем». 
Используя сложное слово finger-ring, аноним не только формально воссоздавал неологизм Дельвига (как правило, finger-ring пишется в два слова, без дефиса), но и усиливал ощущение трагичности происходящего, поскольку finger ring означает не просто подаренное украшение, а «знак брака или помолвки».

У Шарковского также находим перевод «жар-колечка» как «кольца со вставкой», но переводчик подчеркивает компоненты «сверкание» и «искристость», называя камень: I am young and have the ring / With a diamond, on my hand... [11] «Я молода, и у меня кольцо / С бриллиантом на руке».

В случае «жар-колечка» Франс, как кажется, пошел по тому же пути, что и Дэвис, то есть перевел каждую часть сложного слова по отдельности и создал словосочетание, охватившее значение обоих частей: a fiery ring [15] - «огненное кольцо». При этом ясно, что переводчику известен синоним слова «жар», оно переводится буквально как «огонь» или «огненный». Английское fiery имеет значения «цвета огня»; «красный или оранжевый» и может передавать цвет так называемого «красного золота», сплава золота и меди, имеющего красноватый оттенок.

Шесть последних строк стихотворения построены на параллелизмах: это и схожесть и повторяемость событий («...Крупный жемчуг потускнел... Распаялося кольцо... Разлюбил меня милой» [8. С. 31]), и обозначение времени суток и времен года («В день осенний... В зимню ночку... весной» [8. С. 31]). Потускневший жемчуг и распаявшееся кольцо вряд ли обретали какое-то особое значение в англоязычной культуре, поэтому анониму пришлось добавить комментарий «оба этих происшествия являются дурными предзнаменованиями для русской девушки» [10. Р. 107], чтобы связь между тремя упомянутыми событиями стала понятна его читателям.

Строку «Крупный жемчуг потускнел» [8. С. 31] находим в трех вариантах. Глагол «тускнеть» в русском языке имеет довольно объемное значение: «утрачивать яркость красок, блеск, сияние, мутнеть, терять прозрачность». Хотя жемчуг не бывает прозрачным, именно на потерю прозрачности указывает аноним: Were the pearls no longer clear [10. Р. 107] - «Жемчуг не был больше прозрачен», так как clear в этом контексте имеет значение «прозрачный». В переводе Пургиной The pearl beads got dim [12] — «Жемчужные бусины утратили яркость», поскольку контекстным значением прилагательного $\operatorname{dim}$ становится «неяркий». Двое переводчиков выбрали глагол fade - «стать более блеклым, менее ярким»: Pearls were fading on my chest [11] — «жемчуга поблекли на моей груди»; The fine pearl faded on my breast [15] — «дорогой жемчуг поблек на моей груди». Можно сказать, что всем переводчикам удалось подобрать варианты, укладывающиеся в рамки значения русского глагола.

Гораздо труднее оказалось найти подходящие слова, чтобы описать несчастье, приключившееся с кольцом. Кольцо «распаялося», то есть разъединилось в том месте, где его спаяли, сплавили. Это поистине необыкновенное происшествие, поскольку глагол «распаяться» подразумевает нагревание кольца до высокой температуры, когда место спайки расплавилось и кольцо распалось. Переводчики описали это реалистически: And in winter burst my ring, / On my finger, 
of itself! [10. Р. 107] — «И зимой лопнуло мое кольцо / на моем пальце само по себе»; ...was broke my diamond ring [11] — «...распалось на части мое кольцо с бриллиантом» (форма broke не очень удачна, поскольку первое значение этого слова «безденежный, бедный, без гроша»). Причастие II от этого же глагола break использует и Франс, но он выбирает форму broken: The ring was broken on my hand [15] — «Кольцо распалось на части на моей руке». Как кажется, выбор глагола break наиболее удачен: с одной стороны, он также описывает процесс размыкания кольца, с другой, не указывает на конкретный способ, которым кольцо было разъединено.

К переводческим потерям можно отнести опущение слова «ночка», ни один переводчик не воспроизвел его в своем тексте, однако и в народных песнях, и в стихотворении Дельвига ночь, «зимняя ночка», играет важную роль: она символизирует страдания, одиночество, душевные терзания. Исчезновение из переводов «зимней ночки», упоминание лишь «дня» приводит к потере добавочных смыслов, например, When the sad, sad autumn came, / Were the pearls no longer clear; / And in winter burst my ring, / On my finger, of itself! / Ah! and when the spring came on, / Had forgotten me my love [10, p.107] — «Когда пришла печальная, печальная осень, / Жемчуга не были больше прозрачными, / А зимой лопнуло мое кольцо / на моем пальце само по себе, / Ах! и когда весна пришла, / Мой любимый забыл меня». Нужно отметить, что утратив такую важную фольклорную деталь, как противопоставление «дня» и «ночки», аноним все же пытается сохранить народный колорит, введя повтор the sad, sad autumn - «печальная, печальная осень».

Наиболее точно, с сохранением фольклорной окраски, выполнен перевод Питера Франса: On a gloomy autumn day / The fine pearl faded on my breast, / On a frosty winter night / The ring was broken on my hand, / and now the spring is here, / My darling boy loves me no more [15] — «Мрачным осенним днем / дорогой жемчуг поблек на моей груди, / Морозной зимней ночью / Кольцо распалось на части на моей руке, / И вот пришла весна, / Мой миленький дружок больше не любит меня». Надо сказать, что Франс усилил напряжение, нарастающее в заключительных строках стихотворения, использовав прилагательные gloomy (gloomy autumn day - «мрачный осенний день») и frosty (a frosty winter night «морозная зимняя ночь»).

\section{АНАЛИЗ ПЕРЕВОДОВ СТИХОТВОРЕНИЯ «РУССКАЯ ПЕСНЯ («ПЕЛА, ПЕЛА ПТАШЕЧКА...») (1825)}

Второй «русской песней» Дельвига, привлекшей внимание переводчиков, причем только англоязычных, стало стихотворение «Русская песня» («Пела, пела пташечка...») [8. С. 32], опубликованное в 1825 г. Оно является подражанием народной песне «Цвели, цвели цветики...» [2. С. 245] и сохраняет ритмический рисунок этой песни.

Первый перевод этого стихотворения Дельвига, выполненный Ч.Т. Уилсоном (ум. ок. 1880 г.), англиканским священником-миссионером в Бомбее, вышел в 1881 г. Второй перевод появился почти через семьдесят лет, в 1948 г. Его автором стал известный английский литературовед Сесил Морис Боура (1898-1971), переводивший поэзию русского Серебряного Века. 
Как говорилось выше, важным элементом переведенного текста становится название. В переводе Уилсона эпитет в названии опускается и вместо «Русской песни» перед читателем оказывается просто «Песня» без указания ее культурной отнесенности: A Song [18. Р. 77] — «Песня». Боура переводит название полностью: Russian song [19. Р. 14] — «Русская песня», подчеркивая принадлежность стихотворения к иной, русской, культуре.

Перевод названия сразу указывает на стратегии переводчиков: Уилсон безразличен к сохранению национального колорита стихотворения, тогда как Боура старается его сохранить. В первую очередь разница переводческих стратегий проявляется в ритмическом рисунке переводов. Первая строка оригинала состоит из двух хореев и дактиля, вторая - из двух хореев.

Если Боура передает ритм стихотворения Дельвига в переводе, сохраняя, таким образом, главную черту национальной окраски стихотворения, то у Уилсона получается зеркальная картина - ямбы и анапест, причем первая строка удлиняется на один слог.

Слово «пташечка» часто встречается в народных песнях. Уилсон не пытается передать форму слова с уменьшительно-ласкательным суффиксом «-ечк-», в его переводе находим нейтральное bird, которое можем понять и как «птица», и как «птичка». Напротив, Боура находит способ передать и суффикс: a little bird [19. Р. 14] — «маленькая птичка», то есть «небольшая, обычно певчая, птичка», «пташечка».

Перевод Боура по своему характеру приближается к буквальному. Так, в отличие от Уилсона, он прибегает к инверсии, чтобы передать даже порядок слов в первой строфе: Sang a little bird, and sang, / Then was silent; / Knew the heart of happiness, / Then forgot it [19. Р. 14] — «Пела маленькая птичка и пела, / Затем замолчала; / Знало сердце счастье, / Затем забыло его». По сравнению с текстом Боура перевод Уилсона скорее похож на пересказ: The bird that once trilled many a lay / Has lost its song; / The heart to joys, once pleasant, is / A stranger long [18. Р. 77] — «Птица, которая некогда выводила трели во многих песенках, / Потеряла свою песню; / Сердце с радостями, некогда приятными, уже давно не знакомо».

В строфе 3 Уилсон прибегает к конкретизации, заменяя абстрактную «пташечку», которая может быть любой певчей птичкой — коноплянкой, пеночкой, даже соловьем, на lark [18. Р. 77] — «жаворонок». В этом есть свой смысл: жаворонок ассоциируется с весной, поэтому force of snowy blast [18. Р. 77] — «сила сильного порыва ветра со снегом», то есть метели, для него, весенней птицы, особенно губительна. Однако, меняя образность строфы, переводчик удаляется от оригинала. Параллель между force of snowy blast [18. Р. 77] и calumny's / Most wicked breath [18. Р. 77] — «весьма гибельное дыхание клеветы» - сохраняется только на уровне смысла текста. Боура смог сохранить дельвиговскую параллель и по смыслу, и по форме: ... fierce snow-storms... fierce gossip [19. Р. 15] - «жестокие вьюги... жестокие сплетни», причем gossip — «болтовня, сплетни, слухи» - 
достаточно точно передает значение слова «толки» и, к тому же, имеет тот же ритмический рисунок.

Интересную проблему представляет собой слово «мо́лодец», имеющее ярко выраженную фольклорную окраску. Для передачи этого слова Уилсон выбрал нейтральное youth [18. Р. 77] — «юноша», но и «юнец», с помощью которого можно отозваться о человеке неодобрительно. Боура предпочел словосочетание young man [19. Р. 15] — «молодой человек», при помощи которого в русскоанглийских словарях обычно переводится существительное «мо́лодец» с пометкой «поэт.; фолк.».

У каждого из переводчиков в 4 строфе были потери. Боура, которому, как правило, удается сохранить фольклорный колорит текста, заменил формульное выражение «К синю морю» довольно неопределенными blue waters [19. Р. 15] «синими водами», тогда как у Уилсона находим deep blue seas [18. Р. 77] несомненно «синие моря». Заключительная строфа стихотворения «На море валы шумят, / А не вьюги, / В лесе звери лютые, / Да не люди!», как кажется, лучше удалась Уилсону. Он точнее передал мысль Дельвига, выразил ее более отчетливо: Upon the seas rage waves, but not / Snowstorm severe; / Within the woods are fierce wild beasts — / Men fiercer here [18. Р. 77] «На морях бушуют волны, но не / Жестокая метель; / В лесах свирепые дикие звери — / Люди более свирепы здесь». При том, что первая часть строфы у Боура переведена точно: On the sea are roaring waves, / And not snow-storms [19. Р. 15] — «На море ревущие волны, / Но не вьюги», при переводе двух последних строк стремление к точности подвело переводчика: In the woods are untamed beasts, / And not people! [19. Р. 15] — «В лесах неприрученные звери, / А не люди». Мысль о том, что подчас безопаснее находиться рядом с дикими зверями, чем с людьми, сменилась сообщением о том, что в лесах живут не люди, а животные.

\section{АНАЛИЗ СТИХОТВОРЕНИЙ «РУССКАЯ ПЕСНЯ» («АХ ТЫ, НОЧЬ ЛИ...») И «НЕ ОСЕННИЙ ЧАСТЫЙ ДОЖДИЧЕК....}

«Русская песня» («Ах ты, ночь ли...» [8. Р. 51-52]), напечатанная в 1823 г., была переведена Сесилом Морисом Боура и опубликована в 1948 г. По выводам Д.Н. Жаткина, соответствием среди русских народных песен стихотворению Дельвига является песня «Ах ты, ноченька...» [7. С. 23]. Как и при переводе «Русской песни» («Пела, пела пташечка...»), Боура сохраняет ритмический рисунок оригинала - два хорея и дактиль.

Словарь стихотворения «Ах ты, ночь ли...» достаточно нейтрален. В дельвиговом тексте не так много слов, имеющих фольклорную окраску, но Боура очень внимателен к их переводу. В самом начале стихотворения встречаем слово с уменьшительно-ласкательным суффиксом «ноченька», которое Боура переводит словосочетанием с прилагательным little: «Ах ты, ночь ли, / Ноченька!» — Ah, уои night, you / Little night! [20. Р. 13] («Ах, ты, ночь, ты, / Маленькая ночь»).

В отличие от перевода стихотворения «Пела, пела пташечка...» в переводе этого стихотворения много отступлений от текста оригинала, которые сложно 
объяснить. Так, например, отрывок текста, имеющий большое сходство с народной песней, сильно расходится с оригиналом:

И с тобой, знать,

Ноченька,

Как со мною,

Молодцем,

Грусть-злодейка

Сведалась! [8. Р. 51]
'Tis with you, then,

Little night,

As with me here

In my youth.

Wicked sorrow

Summons us! [20. P. 14]
Это же ведь происходит с тобой, Маленькая ночь / ночка,

Как со мною здесь

В моей юности.

Злое горе

Созывает нас!

Даже при столь больших расхождениях Боура постарался передать в переводе сложное слово «грусть-злодейка». Обычно в переводах русских фольклорных текстов, например, сказок, такие сложные слова упрощаются, но Боура выбрал другой путь: он создал словосочетание, каждая часть которого передает смысл части сложного слова, wicked sorrow [20. Р. 14] — «злое горе».

Стихотворение «Не осенний частый дождичек...» (опубликовано в 1829 г.) по форме своей скорее напоминает романс, чем народную песню, поэтому, видимо, оно и не имеет заголовка «Русская песня». Тем не менее, это стихотворение отличают те же формальные черты, что и дельвиговы «русские песни»: в основе его композиции лежит принцип параллелизма, причем осложненный антитезой, тема его «горе-тоска-кручина», при том, что словарь стихотворения достаточно нейтрален, в тексте встречаются слова, требующие особого внимания переводчика: «мо́лодец» и «де́вица». Оно было переведено А.В. Покидовым и опубликовано в 2013 г. Ритм дельвигова стихотворения соблюдается не во всех строках, переводчик отдает предпочтение передаче смысла. Существительное «мо́лодец», которое англоязычные переводчики переводили как young man [19. P. 14] или youth [18. Р. 77], переводится Покидовым как fellow [21], одним из значений которого является «мужчина, мальчик», причем в таком значении это слово в английских толковых словарях идет с пометой old-fashioned - «устаревшее». Для перевода слова «де́вица» также выбран иной, чем у англоязычных переводчиков, вариант - damsel, которое отличается от более привычного maiden стилистической окраской: как и fellow, оно имеет помету «устаревшее» и стилистически принадлежит к тому же регистру, что и «де́вица».

\section{ЗАКЛЮЧЕНИЕ}

Пример «русских песен» Дельвига показывает, что перевод текстов, национальная специфика которых состоит не в наличии реалий, а в особенностях стиля, требует от переводчика не только знаний, но и умения творчески их применять. Перевод «русских песен» можно назвать переводом-стилизацией, поскольку переводчик должен передать не только смысл текста, но и повторить средствами своего языка художественные средства оригинала, что не всегда легко в силу разности языков. У переводчиков русской поэзии на английский язык, особенно поэзии пушкинской поры, уже выработался определенный набор приемов ее перевода, например, использование архаизмов для передачи поэтической лексики в стилизациях под народную поэзию, передача повторов, а если это невозможно, 
то сохранение самого принципа повтора, подбор аналогов для передачи формульных выражений или же создание новых выражений средствами своего языка в рамках своей культуры, замена сложных слов словосочетаниями, в которых передается значение частей этих сложных слов. Анализ «русских песен» Дельвига показал, что еще одним средством передачи национальной специфики текста является его ритм. Точное воспроизведение ритмического рисунка помогает читателю получить то же впечатление от перевода, что и от оригинала, и даже может замаскировать ошибки в передаче содержания.

\section{(C) Ненарокова М.P.}

Дата поступления: 24.08.2018

Дата приема в печать: 26.09.2018

\section{БИБЛИОГРАФИЧЕСКИЙ СПИСОК}

1. Венгранович М.А. Стилистика фольклорного текста. Тольятти: ТГУ, 2011.

2. Томашевский Б.В. А.А. Дельвиг // Дельвиг, А.А. Полное собрание стихотворений. Л.: Советский писатель, 1959. С. 5-58.

3. Ваиуро В.Э. Антон Дельвиг - литератор // Дельвиг, А.А. Сочинения: Стихотворения; Статьи; Письма. Л.: Художественная литература, 1986.

4. Ваиуро В.Э. С.Д.П. Из истории литературного быта пушкинской поры. М.: Книга, 1989. C. $3-20$.

5. Плоткин Л. А.А. Дельвиг // А. Дельвиг. Стихотворения. Библиотека поэта. Малая серия. Л.: Советский писатель, 1951. С. 5-52.

6. Koehler L. Anton Antonovic Del'vig. A Classicist in the Time of Romanticism. The Hague-Paris: Mouton, 1970.

7. Жаткин Д.Н. Поэзия А.А. Дельвига в контексте литературного развития 1810-1830-х годов (традиции и новаторство). Автореферат диссертации на соискание ученой степени доктора филологических наук. М., 2005.

8. Дельвиг А.А. Сочинения: Стихотворения; Статьи; Письма. Л.: Художественная литература, 1986.

9. The North American Review, 1836. pp. 85-120.

10. Delvig A.A. The Faithless Lover. In: Slavic Popular Poetry // The North American Review, 1836. pp. $85-120$.

11. Delvig A.A. Nightingale. Пер. Александр Шарковский. 2011. Режим доступа: http://www.obshelit.ru/works/207978 (дата обращения: 17.08.2018).

12. Delvig A.A. Nightingale Mine. Tr. Lyudmila Purgina. 2012. Режим доступа: https:/www.poemhunter.com/poem/a-delvig-nightingale-mine-the-romance-translation-rus/ (дата обращения: 17.08.2018).

13. Davis Alexis. Selected Russian Classical Romances and Traditional Songs for Young Singers: Introductory Materials with Teaching Strategies. Arizona State University December 2014. Режим доступа: https://repository.asu.edu/.../Davis_asu_0010E_14543.pdf (дата обращения: 17.08.2018).

14. Delvig A.A. Nightingale. Пер. Эдуарда Лейтмана. 2014. Режим доступа: https://www.stihi.ru/ 2014/01/20/8469 (дата обращения: 17.08.2018).

15. Delvig A.A. Russian song. Tr. Peter France. The Penguin Book of Russian Poetry. Robert Chandler, Irina Mashinski, Boris Dralyuk. 2015. Режим доступа: https://books.google.ru/ books?isbn=0141972262 (дата обращения: 17.08.2018).

16. Delvig A.A. Nightingale. Tr. A. Laskavtsev. 2016. Режим доступа: https://lyricstranslate.com/ $\mathrm{ru} / \% \mathrm{D} 1 \% 81 \% \mathrm{D} 0 \% \mathrm{BE} \% \mathrm{D} 0 \% \mathrm{BB} \% \mathrm{D} 0 \% \mathrm{BE} \% \mathrm{D} 0 \% \mathrm{~B} 2 \% \mathrm{D} 0 \% \mathrm{~B} 5 \% \mathrm{D} 0 \% \mathrm{~B} 9-\% \mathrm{D} 0 \% \mathrm{BC} \% \mathrm{D} 0 \%$ BE\%D0\%B9-nightingale.html (дата обращения: 17.08.2018). 
17. Simpson J., Roud S. A Dictionary of English Folklore. Oxford: Oxford University Press, 2000.

18. Delvig A.A. Russian song (The song that once trilled many a lay...) // Wilson C.T. Russian Lyrics in English Verse. L.: Trübner \& CO, 1881.

19. Delvig A.A. Russian song (Sang a little bird...) // A Second Book of Russian Verse. Tr. C.M. Bowra. L.: MacMillan \&Co LTD, 1948. pp. 14-15.

20. Delvig A.A. Russian song (Ah, you night...) // A Second Book of Russian Verse. Tr. C.M. Bowra. L.: MacMillan \&Co LTD, 1948. pp. 13-14.

21. Delvig A.A. 'Tis not autumn's drizzly rain... // The Luminaries of the Odd Pleiad (from D. Venevitinov till P. Vyazemsky). Tr., notes A. Pokidov. Moscow, 2013. Режим доступа: pokidov-poetry.ru〉THE_LUMINARIES.pdf (дата обращения: 17.08.2018).

\title{
THE RUSSIAN SONGS BY ANTON DELVIG: THE PROBLEM OF PRESERVING NATIONAL SPECIFICITY IN ENGLISH TRANSLATIONS
}

\author{
Maria R. Nenarokova \\ A.M. Gorky Institute of World Literature of the Russian Academy of Sciences \\ 25A, Povarskaya str., Moscow, Russia, 121069
}

\begin{abstract}
The article focuses on the problem of reproducing the national specificity of a text in translation. The object is the "Russian songs" by Anton Delvig, stylized as folk songs. They were created with the use of poetic means of Russian folklore. The subject is the peculiarities of reproducing national specificity, typical of Delvig's poems, in English translations. The following texts were analyzed: translations of "Nightingale", "Sang and sang a bird...", "Ah, you, night...", "Tis not autumn's drizzly rain...". The translations were carried out both by English and Russian native speakers. The main objective of the research is to determine what artistic means can convey the national features in a text. The tasks of the study were: to describe conveying metrics; to outline the key words of the poem, describe discrepancies in their translation, explain, why the variant, chosen by a certain translation, is possible or impossible in translating Delvig's text; indicate how the translators reproduce the artistic means of Russian folk songs in English. The continuous sampling method, the descriptive one, the componential one, the conceptual one, the contextual one, that of collocation were used in the course of the study. The study showed that translators preserve the national specifics of the original by creating a stylization in their own language. In the case of Delvig's "Russian songs" the palette of artistic means, conveying national specificity, was developed in the course of a century and a half. It includes archaisms, repetitions and parallelisms, re-creating formulas or creating analogues within the receiving culture. An important means of conveying the national specificity of the text is its rhythm. Accurate conveyng of the rhythm pattern helps the reader to get the same impression from the translation as from the original, and can even mask errors in the reproduction of content.
\end{abstract}

Key words: translation, national specificity, Russian literature, folklore, Russian song, Anton Delvig, stylization, poetic means, "Nightingale"

\section{REFERENCES}

1. Vengranovich, M.A. (2011). The Stylistics of a Folclore Text. A Manual. Tolyatti: TGU. (In Russ.).

2. Tomashevsky, B.V. (1959). A.A. Delvig. In Delvig, A.A. The Complete Poetic Works. Leningrad, the Soviet Writer. pp. 5-58. (In Russ.). 
3. Vatsuro, V.E. (1986). Anton Delvig as a man of letters. In Delvig, A.A. The works. Poems. Articles. Letters. Compilation, commentaries. Leningrad: Hudozhestvennaja literatura. pp. 3-20 (In Russ.).

4. Vatsuro, V.E. (1989). S.D.P. From the History of the Literary Daily Life of Pushkin's Time. Moscow: The Book. (In Russ.).

5. Plotkin, L. (1951). A.A. Delvig. In A. Delvig. Poems. A Poet's Library. The Little Series. Leningrad: The Soviet Writer. pp. 5-52. (In Russ.).

6. Koehler, L. (1970). Anton Antonovic Del'vig. A Classicist in the Time of Romanticism. The Hague-Paris, Mouton.

7. Zhatkin, D.N. (2005). A.A.Delvig's Poetry in the context of the literary evolution in $1810-1830$ (traditions and innovations) [dissertation]. Moscow. (In Russ.).

8. Delvig, A.A. (1986). The works. Poems. Articles. Letters. Compilation, commentaries, introduction by V.E. Vatsuro. Leningrad: Hudozhestvennaja literatura. (In Russ.).

9. The North American Review, 1836. pp. 85-120.

10. Delvig, A.A. (1836). The Faithless Lover. In: Slavic Popular Poetry. The North American Review, 1836. pp. 85-120.

11. Delvig, A.A. Nightingale. Tr. Alexander Sharkovsky. 2011 URL: http://www.obshelit.ru/ works/207978 (accessed: 17.08.2018).

12. Delvig, A.A. Nightingale Mine.Tr. Lyudmila Purgina. 2012. URL: https://www.poemhunter.com/ poem/a-delvig-nightingale-mine-the-romance-translation-rus/ (accessed: 17.08.2018).

13. Davis, Alexis. Selected Russian Classical Romances and Traditional Songs for Young Singers: Introductory Materials with Teaching Strategies. ARIZONA STATE UNIVERSITY December 2014. URL: https://repository.asu.edu/.../Davis_asu_0010E_14543.pdf (accessed: 17.08.2018).

14. Delvig, A.A. (2014). Nightingale. Tr. Edward Leitman. URL: https://www.stihi.ru/2014/01/20/8469 (accessed: 17.08.2018).

15. Delvig, A.A. Russian song. Tr. Peter France. The Penguin Book of Russian Poetry. Robert Chandler, Irina Mashinski, Boris Dralyuk, 2015 URL: https://books.google.ru/books?isbn=0141972262 (accessed: 17.08.2018).

16. Delvig, A.A. Nightingale. Tr. A. Laskavtsev. 2016. URL: https://lyricstranslate.com/ru/\% D1\%81\%D0\%BE\%D0\%BB\%D0\%BE\%D0\%B2\%D0\%B5\%D0\%B9-\%D0\%BC\%D0\%BE\% D0\%B9-nightingale.html (accessed: 17.08.2018).

17. Simpson, J, Roud, S. A Dictionary of English Folklore. Oxford University Press, 2000. P. 411.

18. Delvig, A.A. Russian song (The song that once trilled many a lay ...). Wilson C.T. Russian Lyrics in English Verse. L, Trübner \& CO, 1881.

19. Delvig, A.A. Russian song (Sang a little bird...). A Second Book of Russian Verse. Tr. C.M. Bowra. L, MacMillan \&Co LTD, 1948. pp. 14-15.

20. Delvig, A.A. Russian song (Ah, you night...). A Second Book of Russian Verse. Tr. C.M. Bowra. L, MacMillan \&Co LTD, 1948. pp. 13-14.

21. Delvig, A.A. 'Tis not autumn's drizzly rain... The Luminaries of the Odd Pleiad (from D. Venevitinov till P. Vyazemsky). Tr., notes A. Pokidov. Moscow, 2013. URL: pokidovpoetry.ru>THE_LUMINARIES.pdf (accessed: 17.08.2018).

\section{Для цитирования:}

Ненарокова М.Р. «Русские песни» Антона Дельвига: проблема сохранения национального колорита в английских переводах // Вестник Российского университета дружбы народов. Серия: Теория языка. Семиотика. Семантика, 2018. Т. 9. № 4. С. 795-811. doi: 10.22363/23132299-2018-9-4-795-811.

\section{For citation:}

Nenarokova, M.R. (2018). The Russian Songs by Anton Delvig: The Problem of Preserving National Specificity in English translations. RUDN Journal of Language Studies, Semiotics and Semantics, 9(4), 795-811. doi: 10.22363/2313-2299-2018-9-4-795-811. 


\section{Сведения об авторе:}

Ненарокова Мария Равильевна, доктор филологических наук, ведущий научный сотрудник Института мировой литературы им. А.М. Горького РАН; научные интересы: история средневековой культуры, средневековой латинской литературы, богословия; жанры средневековой литературы, средневековая школа; английская, датская, русская литература эпохи романтизма; язык цветов; компаративные исследования, переводоведение, преподавание перевода; e-mail: maria.nenarokova@yandex.ru

\section{Information about the author:}

Maria R. Nenarokova, Doctor of Philology, Leading Researcher of A.M.Gorky Institute of World Literature of the Russian Academy of Sciences; Interests: history of Medieval Culture, Medieval Latin literature, Medieval education; English, Danish, Russian Literature of Romanticism; Russian Orthodox Spirituality, Russian Culture of the 19th century; the language of flowers; comparative studies, translation and interpretation studies; e-mail: maria.nenarokova@yandex.ru 